\title{
Special Issue on Timber in Fire
}

\author{
Luke A. Bisby*, Arup Chair of Fire and Structures, BRE Centre for Fire Safety \\ Engineering, School of Engineering, University of Edinburgh, Edinburgh \\ EH9 3JL, UK \\ Andrea Frangi, Institute of Structural Engineering, ETH Zurich, 8093 Zurich, \\ Switzerland
}

Timber is amongst the oldest building materials used by humankind. We have been building with timber for millennia, and in its various forms timber has consistently remained a key structural and building material in most cultures (along with masonry and, more recently, concrete and steel). However, various conflagrations in largely timber-built towns and cities around the world throughout the history of civilization - typically called the "Great Fires" (e.g. of Rome, Constantinople, Hangzhou, Utrecht, Amsterdam, London, Baltimore, Tokyo, etc.) - led to the use of timber structural and cladding materials being reduced or explicitly restricted within dense conurbations, with a preference for non-combustible structural framing, cladding, and roofing materials - particularly for multistory and high-rise construction.

In most places, timber has remained a critically important and widely used building material in a range of applications, however during recent centuries the structural use of timber (either as heavy timber elements or light timber framing) has typically been limited to low-rise construction of smaller volume buildings with fewer than four-to-five storeys; the use of timber cladding has also been widely restricted or avoided.

However, spurred on by the sustainability and constructability credentials of timber as compared with concrete, masonry, or steel - and by the development of novel engineered timber materials and prefabricated systems incorporating engineered timber joists and trusses, glued-laminated timber (glulam) and cross-laminated timber (CLT) - timber has experienced an accelerating resurgence/emergence as a primary material in multi-storey buildings [1].

A range of publications during the past 5 years has highlighted the opportunities to build large, multi-storey buildings in engineered timber [2-4]. Timber buildings of up to nine or ten storeys are increasingly being proposed internationally, and numerous proposals have been made for predominantly timber - or hybrid timber-steel or timber-concrete-buildings of 30 storeys or more [2]. Timber is also increasingly being proposed by architects and engineers for innovative, sustainable, and attractive building facades and cladding systems.

\footnotetext{
* Correspondence should be addressed to: Luke A. Bisby, E-mail: luke.bisby@ed.ac.uk
} 
Despite its advantages and sustainability credentials, timber is combustible and presents special fire safety challenges as compared with concrete and steel-neither of which is without its own challenges. The fire safety community must work together to collectively ensure that the relevant fire safety challenges for timber buildings are knowingly and appropriately addressed during design, application, and use; so as to avoid the problems of the past and ensure that timber can be safely used to support the global push for sustainable urbanism and increased urban density.

The papers compiled within this special issue of Fire Technology address a range of key fire safety issues and applications of timber in modern buildings, including: the structural fire resistance for both solid timber [5] and engineered timber elements in glulam [6] or CLT [7], and light frame engineered timber flooring systems [8] as well as connections in timber [9, 10]; the specific fire dynamics in building compartments made from massive or light frame timber elements [11]; the fire protection capabilities of timber materials [12]; and the fire-safe use of timber cladding materials for multi-storey buildings [13].

The breadth of coverage of key considerations in this special issue is, from our perspective, surprisingly (and serendipitously) complete. While it is clear that considerable additional research is needed in support of essentially all of the research areas presented, it is also evident that - with sufficient fire safety knowledge, education, skill, additional research, and care during design and application-fire safety considerations need not prevent the use of timber in multi-storey buildings.

\section{References}

1. Barber D (2015) Letter to the editor - tall timber buildings: what's next in fire safety?. Fire Technol. doi:10.1007/s10694-015-0497-7

2. Gerard R, Barber D, Wolski A (2013) Fire safety challenges of tall wood buildings: final report. Fire Protection Research Foundation

3. Buchanan A, Östman B, Frangi A (2014) Fire resistance of timber structures: a report for the National Institute of Standards and Technology. http://www.nist.gov/el/fire_research/ upload/NIST-Timber-Report-v4-Copy.pdf

4. SP Technical Research Institute of Sweden (2010) Fire safety in timber buildings - technical guideline for Europe. SP Report 2010:19

5. Schmid J, Just A, Klippel M, Fragiacomo M (2014) The reduced cross-section method for evaluation of the fire resistance of timber members: discussion and determination of the zero-strength layer. Fire Technol. doi:10.1007/s10694-014-0421-6

6. Lange D, Boström L, Schmid J, Albrektsson J (2015) The reduced cross section method applied to glulam timber exposed to non-standard fire curves. Fire Technol. doi:10.1007/ s10694-015-0485-y

7. Schmid J, Menis A, Fragiacomo M, Clemente I, Bochicchio G (2015) Behaviour of loaded cross-laminated timber wall elements in fire conditions. Fire Technol. doi:10. 1007/s10694-015-0516-8

8. Sultan MA (2012) Fire resistance of wood truss floor assemblies. Fire Technol. doi:10. 1007/s10694-012-0311-8

9. Maraveas C (2013) Performance of timber connections exposed to fire: a review. Fire Technol. doi:10.1007/s10694-013-0369-y 
10. Gilani MS, Hugi E, Carl S, Palma P, Vontobel P (2014) Heat induced desorption of moisture in timber joints with fastener during charring. Fire Technol. doi:10.1007/ s10694-014-0416-3

11. Li X, Zhang X, Hadjisophocleous G (2014) Experimental study of combustible and non-combustible construction in a natural fire. Fire Technol. doi:10.1007/s10694-0140407-4

12. Östman B, Boström L (2014) Fire protection ability of wood coverings. Fire Technol. doi:10.1007/s10694-014-0452-z

13. Östman B, Tsantaridis L (2015) Fire scenarios for multi-storey façades with emphasis on full-scale testing of wooden façades. Fire Technol. doi:10.1007/s10694-015-0508-8 